\title{
The Tiv Socio-Cultural Environment and Entrepreneurship Emergence
}

\author{
Clement C. M. Ajekwe ${ }^{1 *}$ Adzor Ibiamke ${ }^{2}$ \\ ${ }^{I}$ Department of Accounting, Benue State University, Makurdi \\ ${ }^{2}$ Department of Management Science, Kwararafa University, Wukari
}

\begin{abstract}
The paper assesses the Tiv socio-cultural environment and considers its effect on the emergence of entrepreneurship. A qualitative methodology was adopted based essentially on a theoretical survey, scattered observations and random access to some features of the Tiv socio-cultural environment, and a discussion of their implications for the emergence of entrepreneurship. Certain Tiv socio-cultural features and history,- such as attitudes towards wealth, authority and leadership, work and leisure, savings and the formal education system,- were "found" to be capable of either inhibiting their entrepreneurship development or holding back in check any desire to engage in entrepreneurial activity. However, because of the new and emerging realities in Nigeria, socio-cultural values of ethnic groups, including that of the Tiv are changing. Tiv individuals are urged to learn how to convert the weaknesses in their socio-cultural environment to advantage and to create opportunities to launch them into entrepreneurship.
\end{abstract}

Keywords: Tiv, Entrepreneurship, Socio-Cultural Environment

\section{Introduction}

The economic realities of the Tiv people of central Nigeria with experiences of economic hardship, unemployment and poverty, in much recent time, has made the role of entrepreneurship development in Tivland crucial. While the Tiv people have certain socio-cultural values that can be applauded, they are nevertheless associated with cultural practices that inhibit entrepreneurship hence a need for reorientation. Prior studies have indicated that entrepreneurship has the ability to create wealth and employment for individuals, society as well as the country (Drucker, 1985). While some prior studies illustrate the importance of entrepreneurship, several others have indicated that it can be inhibited by an anti-entrepreneurial culture. The fact that the culture of a people can encourage or discourage start-ups is depicted by the significant differences in the levels of entrepreneurship among different ethnic groups of a country. For instance, people of Shanghai are said to be more entrepreneurial than people from Beijing (Sheller, 2005); the Igbo and Ijebu of Nigeria and the Kikuyu of Kenya are well known as having a socio-cultural environment which predisposes them towards entrepreneurship more than other ethnic groups in their respective countries (Nafukho, 1998). Several other researchers support this view (McClelland, 1961; Weber, 1976; Aldrich \& Waldinger, 1990; Light \& Rosenstein, 1995; Thomas \& Mueller, 2000; Harrison \& Huntington, 2000).

Culture is defined as a set of shared values, beliefs, and behaviours (Hofstede, 1980). Deeply embedded, shared values shape political institutions as well as social and technical systems of an ethnic group. In our context, all manmade intangibles that have direct or indirect effect on the peoples' behaviour and the total way of life in relation to career choice are referred to as the socio-cultural environment (Akpor-Robaro, 2012). Cultural values indicate the degree to which a society considers entrepreneurial behaviours, such as risk taking and independent thinking, to be desirable. Cultures that value and reward such behaviours promote a propensity to develop and introduce radical innovations, including entrepreneurship; whereas cultures that reinforce conformity, group interests, and control over the future are not likely to show risk-taking and entrepreneurial behaviours (Herbig \& Miller, 1992; Herbig, 1994; Hofstede, 1980). Entrepreneurs, that is, business owners are shaped by the factors of their socio-cultural environment. Tiv is the fourth largest of the over 200 ethnic groups in Nigeria; with an estimated population of twelve million. The Tiv, like the other Nigerian ethnic groups, have distinct cultural values, beliefs and practices. They speak a common language and claim a common ancestral origin. They inhabit Central Nigeria in the states of Benue (where they are the majority ethnic group), Nasarawa, Taraba, Plateau, Cross River and Kogi, including the Federal Capital Territory, Abujaand the Republic of Cameroon. This paper seeks to assess the socio-cultural environment of the Tiv and how it impacts entrepreneurship emergence within its membership. It is important, therefore, to understand the Tiv sociocultural environment and its potential influence on entrepreneurship. 


\section{A Theoretical Perspective Of Culture's Association With Entrepreneurship}

Culture is progressively acknowledged as an important factor contributing to promote or inhibit entrepreneurship in a society (OECD, 2004). Hence, the influence of culture on entrepreneurship is a topic that researchers have been interested in, with national, regional, as well as ethnic cultures under investigation (George \& Zahra, 2002). Several theories have tried to explain the social and cultural characteristics which cause people to be or not to be entrepreneurs. Such theories include Hofstede's cultural dimensions' theory, McClelland's need for achievement theory, Max Weber's religion theory, the educational incubation theory and the displacement theory. However, only Hofstede's culture theory is accessed in this paper.

\subsection{Hofstede's Cross-Cultural Theory}

Hofstede $(1980,1991)$ investigated IBM workers in more than 50 countries to identify values useful in cross-cultural management. Hofstede (1980) originally identified and described four cultural dimensions to which a fifth was later added as follows:

\subsubsection{Uncertainty avoidance}

Uncertainty avoidance describes the extent to which a culture tolerates and adapts to uncertainty through the domains of technology, law, and religion (Hofstede, 2001). Uncertainty avoidance tends to discourage risk-taking and encourage modifying innovations to meet traditional organizational norms (McGrath, MacMillan, \& Scheinberg, 1992; Shane et al., 1995), thereby reducing a culture's tendency toward entrepreneurial behaviour. Individuals in societies high on uncertainty avoidance prefer the status quo. Individuals in societies low in uncertainty avoidance are comfortable with ambiguous situations and change including the uncertain world of self employment.

\subsubsection{Power distance}

Power distance has been described as the extent to which people in a society accept differences in power and status between its members (Hofstede, 2001; Mitchell et al., 2000). Cultures with high power distance tend to be more hierarchical and centralized in their decision-making; whereas cultures with relatively low power distance tend to be more egalitarian and democratic. Low power distance has been associated with entrepreneurs and entrepreneurial cognition and activity (McGrath, MacMillan, \& Scheinberg, 1992; Mitchell et al., 2000).

\subsubsection{Individualism or collectivism}

As a cultural dimension, individualism reflects the extent to which individual ties are relatively loose and people tend to be responsible only for themselves and their immediate families. This is contrasted with collectivism, which reflects societies where people are born into cohesive in-groups of which they will be a member for life (Hofstede, 2001). Research suggests that this dimension is much less subject to external influence than either power distance or uncertainty avoidance (McGrath, MacMillan, Yang, \& Tsai, 1992). The lack of malleability of this dimension suggests that the relatively high emphasis on individual achievement may limit entrepreneurial behaviours in collectivist cultures.

\subsubsection{Masculinity or femininity}

While cast in gender-oriented terms, Hofstede's (1980) masculinity-femininity dimension actually measures characteristics such as the extent to which a culture values work goals such as advancement, responsibility, and earnings relative to personal relationships, helping others, and the physical environment. Initial research in national culture and entrepreneurship suggest that entrepreneurs tend to be more masculine than non-entrepreneurs (McGrath, MacMillan, \& Scheinberg, 1992) and the masculinity dimension's orientation toward earnings and achievement suggest an affinity toward wealth creation. The relationship between entrepreneurial orientation and wealth creation will be particularly strong in masculine cultures. This is because the focus on goal accomplishment and financial earnings in these cultures help to create a rewards system that encourages characteristics associated with entrepreneurial orientation such as risk taking and pro-activeness.

\subsubsection{Time orientation}

Time orientation index measures the extent to which a society is focused on the future or on the present and the past. A society that has a long-term orientation encourages savings and persistence among its population. Conversely, members of a society with a short-term orientation focus on the past by respecting tradition and meeting social obligations and on the present by living to enjoy the moment as if there is no tomorrow. 


\subsection{A Conceptual Model of Association of Culture with Entrepreneurship}

Two broad streams of research studies have examined the values, beliefs, motivations and cognitions of entrepreneurs across cultures. The first stream of research studies show that broad cultural characteristics based on Hofstede's $(1980,1991)$ cultural dimensions (individualism-collectivism, uncertainty avoidance, power distance, masculinity-femininity and long-term versus short-term orientation) are significantly associated with national and regional (ethnic) levels of entrepreneurship (Shane, 1992\&1993; Davidsson, 1995; and Davidsson \& Wiklund, 1995). The expected associations of these cultural dimensions and entrepreneurship have been covered extensively in the literature (e.g. Herbig, 1994; Hofstede, 1980; Shane, 1992). In general, researchers have hypothesized that entrepreneurship is facilitated by cultures that are high in individualism, high in masculinity, low in uncertainty avoidance, and low in power distance. All things being equal, it is expected that the greater the cultural distance from this ideal type, the lower the average individual and aggregate levels of entrepreneurship.The second stream of research studies addressed the association between culture and the characteristics of individual entrepreneurs (McGrath \& MacMillan, 1992; McGrath et al., 1992; Mueller \& Thomas, 2000; Thomas \& Mueller, 2000). On the whole, these studies identify a number of entrepreneurial characteristics that appear to be influenced consistently by (national) culture. Specifically, there is strong evidence that self reported reasons for starting a business vary systematically with variations in culture along dimensions of individualism, power distance and masculinity (Scheinberg \& MacMillan, 1988; Shane et al., 1991). Furthermore, cultural values such as individualism and uncertainty avoidance are significantly related to traits such as internal locus of control, risk taking and innovativeness, which are associated with entrepreneurship (Mueller \& Thomas, 2000; Thomas \& Mueller, 2000).

These studies provide two key insights into the role of culture in entrepreneurship: (i) in the context of entrepreneurship, theories of motivation are culture bound in that different cultures emphasize different motivational needs; and (ii) culture is likely to influence national, regional or ethnical rates of entrepreneurship by creating a larger supply of potential entrepreneurs.The relationships among studies reviewed is depicted in a model of the association between culture and entrepreneurship (Figure 1) According to the model, culture in all its dimensions, moderates the relationship between contextual factors and entrepreneurial outcomes; highlighting the role of culture as a catalyst rather than the cause of entrepreneurial outcomes. The model suggests that cultural characteristics transform and complement institutional and economic contexts to influence entrepreneurship. Other moderators included in figure 1 are needs and motives and beliefs and behaviours.

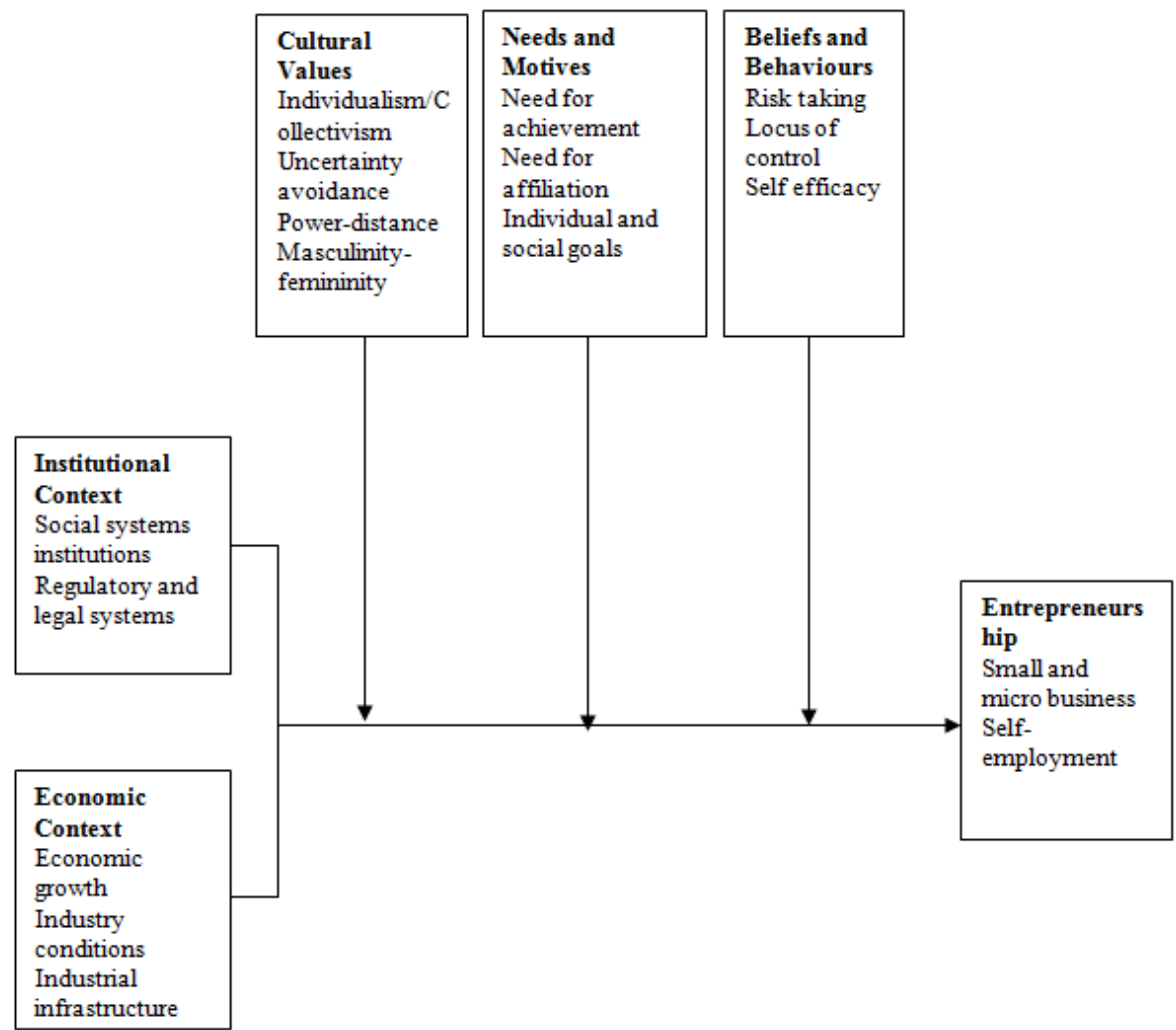

Figure 1. Model of the Association between Culture and Entrepreneurship

Source: Hayton, J., George, G. and Zahra, S. (2002). National culture and entrepreneurship: A Review of behavioural research. Entrepreneurship Theory and Practice, 26(4):46. 


\subsection{Culture of Entrepreneurship}

Ethnic groups or regions that have a cultural propensity towards entrepreneurship are said to have entrepreneurial culture (Shiller, 2005). Once an entrepreneurial culture takes root it typically spreads locally as people learn about business and begin to feel attracted to it even if it doesn't yield an immediate or certain pay off (Gianetti \& Simonev, 2007). An entrepreneurial culture (i) is seen as a set of values, beliefs and attitudes commonly held by society that support the notion that an entrepreneurial life system is desirable; (ii) strongly supports the search for effective entrepreneurial behaviour within its membership (Gibb, 1996); (iii) accords high prestige to entrepreneurs who then enjoy high social status in society, regardless of whether or not they are already successful; (iv) nurtures individuals in original and significant ways (Joynt \& Warner, 1966); and (v) places a high value on independence which allows for less conformity and is more tolerant toward inequalities of income and wealth (Licht, 2007:850; Giannetti \& Simonov, 2004:269). It does not look down or stigmatize entrepreneurs who have tried but failed, rather it recognizes the positive influence of entrepreneurs on society and their role in serving as the essential incubator in the entrepreneurship initiation process (Johannison, 1987). Entrepreneurial cultures score high on Hofstede's (1980 \& 1991) value dimensions of individualism and masculinity; but low on uncertainty avoidance (Mueller \& Thomas, 2000; McGrath, MacMillan \& Scheinberg, 1992).

\subsubsection{Aspects of Entrepreneurial Culture}

Several factors contribute to an entrepreneurial culture including: (i) consequences of history; (ii) ideological beliefs and practices of an ethnic group and (iii) the dominant cultural attitudes, values and beliefs of an ethnic group.

\section{Consequences of history}

The resultant consequence of history on a society determines the extent to which their structures are designed to enable expression of individualism and collectivism, conformity or deviancy, equality or hierarchy and masculinity or femininity (Hagget, 1983; Hornaday \& Aboud, 1971). These are political and social systems which serve to grow people who are either fostered or lacking in the personal attributes generally associated with entrepreneurship, particularly leadership, creativity, independence, achievement orientation, self reliance and self confidence.

\section{Ideological practices}

Ideological practices of a population refer to their pattern of thinking (Burrows, 1991). In some societies, such as the USA, entrepreneurs enjoy a high status regardless of whether or not they are already successful (Lamont, 1994). Other societies, such as Pre-Thatcher Britain, look down on entrepreneurs, holding them out to be low achievers who could not be trusted (Chell et al, 1991). However, as noted by Chell et al., (1991:37), this ideology has changed in the post-Thatcher Britain: Historically the British culture was such that its high achievers were creamed off for top jobs in administration and government. Self-employment was not regarded as an attractive option until the popularization of the "enterprise culture" of the Thatcher era of the 1980's.Some societies have a low tolerance for failure. Such societies stigmatize entrepreneurs who have tried but failed. Other societies applaud entrepreneurial initiatives and failure in enterprise has few associated negative connotations. Rather, the significance and value of having applied personal initiative and enterprise albeit unsuccessfully is viewed positively. In contrasting the UK and USA on this ideological practice, Chell et al, (1991:37) observed that "(The) British attitude toward self employment together with the stigma attached to business failure is not evident in the United States, for instance, where failure is seen as a positive learning experience".

Furthermore, within some societies there is a practice of saving for the future, while in others, the focus is on living and spending to enjoy the moment. This has adverse implications for the amount of personal funds that may be available for investment in business. For example, writing on the Tiv economy during the 19151950 period, Makar (1994) documented the expected effect of the construction of the eastern railway line in the 1920 's cutting across Tivland in stimulating economic activity; considering that about 28,000 Tiv were conscript labourers on the railway line and the Benue Bridge at Makurdi. The colonial administration expected that these conscript labourers would increase the wealth of their land, but regretted that their earnings did not add any wealth to the Tiv society because, according to official British Administration Reports, 1923 (quoted by Makar, 1994: 150) "The young men spent or gambled away their money as soon as they received it and the ubiquitous Hausa traders collected the greater part of it".

\section{Dominant cultural attitudes, values and beliefs}

Socio-cultural attitudes, values and beliefs of a group at one particular point in time result in a particular common mindset relative to the degree to which entrepreneurship is supported by society (Gilder, 1971). In particular, the extents to which cultural attitudes are communal or individualistic have been identified 
as significant (Morrison 1998). Societies that predominantly hold strong communal and collective values do not support individualistic wealth creation through entrepreneurship, while those with strong individualistic values generally do. Furthermore, in societies where there are moral obligation to provide for the community, the priority for income earned is to the community rather than to investment in private enterprise.

With this background, the paper proceeds as follows: the next section surveys the Tiv socio-cultural environment; section 4 analyzes and discusses the Tiv socio-cultural environment; and section 5 concludes the paper.

\section{Tiv Socio-Cultural Environment And Entrepreneurship}

The Tiv social organization is based on kinship and lineage. People who are "kith and kin" settled together. Traditionally, the Tiv society scorned individualism and was apprehensive of anyone who embraced it. Such a person was thought dangerous in society for he was moving toward an innovation which had not been tested before and it was feared that the act might affect the carefully structured balance of the whole society. For this reason, an individual who, through hard work or good fortune rose above others was said to be putting everyone in danger of arousing inimical forces (tsav) in the cosmos. So much was the force of kinship and lineage institutions and the social security that living in them provided that Bohannan and Bohannan (1968) opined that they "could hold in check any desire to engage in entrepreneurial activity---for to enjoy the proceeds, one had to share it among kinsmen or be ostracized by them"

\subsection{Aspects of Tiv Social-Culture}

This paper proposes that certain aspects of Tiv culture are capable of either inhibiting entrepreneurship development among its membership or holding back in check any desire to engage in entrepreneurial activity. The particular aspects identified in this paper are six: Tiv attitudes towards wealth, authority and leadership, work and leisure, savings, the formal education system and their communal living. These aspects of Tiv culture are discussed ad seriatim:

\subsubsection{Tiv attitude to wealth}

The Tiv had a culture which valued prestige over and above wealth. The items the Tiv valued were not material things or marketable goods at all. Rather, the number of dependents, kinship (angbianev) and prestige (shagba) were valued instead of money or other measures of wealth as viewed by other ethnic groups like the Igbo. In the Igbo culture, for example, financial wealth is cherished because it is the basis for social recognition and status. Among the Igbo therefore, self employment (i.e., entrepreneurship) provides faster legitimate means to wealth, economic power, recognition and status. The Tiv on the other hand, deprecated living on profit and were scornful of the individual who is rich in money but lacks the basic goal for social maximization. In particular, no person would gain in wealth controlling and exploiting the labour of others. If any Tiv person tried it, such a person would to be said to have had very bad tsav (Bohannan \& Bohannan, 1968). The implications of Tiv attitude to wealth relative to entrepreneurship should be obvious: entrepreneurship, by definition, is wealth creation which can result in inequalities in the distribution of wealth. As suggested above, the Tiv are not comfortable with disproportionate inequalities in incomes and wealth distribution.

\subsubsection{Tiv attitude toward authority and leadership}

Tiv society is generally paternalistic and hierarchical and of little prone to individualism. It tends to be egalitarian within the same age set (kwav) but hierarchical in group-to-group relations with marked subordination of the younger age sets. Within each set, individuals possess equal social status unlike say, the Igbo where wealth determines a person's social status. Because Tiv culture was not achievement-oriented, superior achievement of a member within an age-set, did not guarantee an automatic catapult of the achiever outside his or her age circle to a higher circle. Hierarchy based on age and ascription is not considered an aspect of "entrepreneurial culture". Entrepreneurs value an achievement culture more than an ascription culture (Hornaday \& Aboud, 1971).

\subsubsection{Tiv attitude to work and leisure}

Judged by standards of charity and solidarity, the Tiv have an impressive culture. The Tiv value group solidarity and occasions of socializing which have generally led to a tendency to attach a high value to leisure and the attendant ability to engage in social activities such as marriages, burials, naming ceremonies and attendance at church ceremonials (for "thanksgivings, for example). The high value attached to "socializing" has often been misconstrued by westerners as "laziness" or even as "wasteful". Simply put, these activities and attendance at them, serve as a means of reinforcing social bonds which are the foundation of the Tiv society. Thus, the marginal return for "leisure" is generally very high; but the benefits are more social than economic. By this culture, it is expected therefore that the Tiv response to income incentives, be it in agriculture, 
entrepreneurship or any other "productive endeavour", will be positive only if the expected increase in the leisure/income trade off will not only materialize within a short time horizon, but also will be striking. At the moment, it is mainly entry into politics, being political touts and thugs that guarantee substantial and immediate pay off. A good number of Tiv youths are seeking a career in politics, touting and being political thugs. As entry into politics is seen as guaranteeing substantial and immediate pay-off; there is very strong temptation for Tiv entrepreneurs to combine business with politics or even to abandon entrepreneurship for politics. Tiv pioneer entrepreneurs, like Ugoo Iywoo, Akaazua Muemue, etc, are known more as politicians than as entrepreneurs. Unfortunately, explorations by entrepreneurs into politics have, in general, tended to shorten the lives of their enterprises through activities of political thugs and intrigues that envelop and choke them.

\subsubsection{Tiv attitudes towards savings}

To the Tiv, the only riches are those shared with and are socially visible to the community. There is the social and mystical need for what westerners may call "wastefulness". Examples include expensive burials, naming ceremonies and lavish entertainment, sometimes involving excessive consumption of alcohol, the slaughter of domestic animals on a massive scale, etc. Regarding expensive burials, both the catholic and protestant churches have introduced codes that are intended to prohibit or limit some of these extravagant expenditures only to see them circumvented by their adherents.Exacerbating matters is the philosophy of " $k a$ kwagh u a lu u ken uya la a lu u wou ye" and the fact that the extended family is always present and likely to be imposing. When small in size, excess income is distributed first to members of the "immediate family", then to the "extended family" and then to the larger community. Increased income, therefore, simply leads to more lavish consumption and a widening of the circle of those benefiting from the income re-distribution. A corollary is that economic success in itself did not lead to upward social mobility. Most of this wealth generally ended up in conspicuous consumption; buying unmerited chieftaincy titles, luxury non-commercial homes in several locations, latest car models, lavish social festivities and trying to please everyone in the extended family all at once, instead of productive investments.

To what can these seemingly irrational behaviour traits be attributed? The need for patronage may be a primary justification. The host who provides sumptuous hospitality and redistributes his wealth can expect to count on the beneficiates in periods of need (such as when seeking elective office). A desire for shagba (prestige) or a communication of "social arrival" frequently provides a second reason. A third possible explanation may be related to a "culture of poverty" (Thompson and Wildavsky, 1986), the characteristics of which are (i) Short-termism: why look to the future if you cannot outguess Mother Nature?; (ii) Unwillingness to invest: Why invest if you cannot know whether you will die the next day?; (iii) Lack of personal responsibility: why take responsibility if the future is unknowable; what if other people are likely to undercut you no matter what you do?; and (iv) Fatalism: life is too short; eat and be merry for you do not know when the hour will come; after all, "ka kwagh u a lu u ken uya la a lu u wou ye" From the economic development and entrepreneurial perspective, this tendency of attaching little value to self control needed for savings runs counter to the pre-requisites for promoting private investment and entrepreneurship.

\subsubsection{Tiv formal education}

A country's education system plays a significant role in the initiation of characteristics generally associated with entrepreneurial development (Gibb, 1996). Nigerian educational institutions, particularly primary schools are very weak breeding grounds for future entrepreneurs. In these institutions, children are inculcated with conformist ideals while their natural curiosity is suppressed. The children are taught how to obey and respect senior people and that success of their future careers can only accrue from thus type of conformist behaviour; a teaching which parents consolidate and reinforce at home. Thus the inculcation of conformist ideals; at school and at home; together with the powerlessness it generates in the children; results in a dependency syndrome which seriously erodes the development of entrepreneurial traits such as self confidence and decision making ability.

\subsubsection{Tiv communal living.}

In times past, the Tiv practised a policy of "communalism" or "collectivism". By this policy, all activities, like tilling the land, building living quarters, food security etc were approached collectively. Even children belonged to the collective society. The communal approach to life has implications on entrepreneurial behaviour. It does not encourage a savings culture. It is quite common that a Tiv person in regular employment supports ten members of his or her community in one way or the other. It therefore becomes very difficult to accumulate sufficient savings with which to invest in a new business. Without investments, there will be no jobs that can increase the number of working population and reduce the number of "mouths" one person has to feed. In this way, the communal spirit becomes a millstone around the necks of aspiring Tiv entrepreneurs, acting as an inhibitor of entrepreneurial development. 


\section{Analysis And Discussion}

The paper adopts a qualitative methodology based essentially on a theoretical survey, scattered observations and some qualified reasoning of the features of the Tiv socio-cultural environment, to analyze and discuss their effect on the emergence of entrepreneurship.Tiv socio-cultural features are related to Hofstede's (1980 \& 1991) cultural dimensions to ascertain their fit with a culture of entrepreneurship. The Tiv are said to originate from present DR Congo (Abraham, 1934). That the Tiv migrated from the Congo; passing through several places before settling at their present location in the Benue valley, is an indication of a people low in uncertainty avoidance. As noted in section 2.1.1, an ethnic group low in uncertainty avoidance is comfortable with uncertainty, including the uncertain world of business ownership. However that they lived in tightly knit communities suggests a high uncertainty avoidance. On the other hand, the Tiv settlement pattern could have been a military strategy to thwart attacks from other ethnic groups who inhabited the Benue valley before their arrival.A culture with low power distance (i.e., an egalitarian culture), suits entrepreneurship more than a high power distance culture where it is assumed only certain families, royalty or persons of particular age can own and operate businesses. The Tiv society exhibits characteristics of both high and low power distance. It is paternalistic and tends to be egalitarian within the same age set but hierarchical in group-to-group relations with marked subordination of the younger age sets. Paternalism tends to weaken its beneficiaries by depriving them the development of personal attributes generally associated with entrepreneurship particularly leadership, creativity, independence, achievement orientation, self reliance and self confidence. The communal character of the Tiv predisposes them to collectivism which has negative implications for entrepreneurship; as it causes the individual to lose his/her sense of independence, self initiative, motivation, and internal locus of control to the group; shifting their locus of control externally to the community.

In general, the Tiv exhibit a feminine culture. The ya na angbian philosophy for example, obsession with taking care of the weaker members of society and considerations for others' interests are examples of feminine aspects of Tiv culture. While this acts as a strong bond of the Tiv, the feminine culture is not forceful enough to motivate its membership into entrepreneurial ventures. Furthermore, some aspects of Tiv behaviours suggest a culture with a short-term orientation. East (2003:376-377) captured these aspects which have been paraphrased as follows:Another trait in the Tiv character is their lack of perseverance. They can never keep doing the same thing for any length of time. The Tiv have no care for the future. That is how the Tiv suffer from their improvidence Furthermore, their attitude to savings and communal living are pointers to a shortterm orientation, which negatively impacts capital accumulation and inhibits entrepreneurship development. The number of Tiv university graduates and others with specialized or higher qualifications has increased fantastically. However, Tiv business owners are mostly with limited to modest formal education. Highly educated people "know" their status and have a phobia for risk/failure; consequently they tend to shy away from self employment, preferring to work in the "secure" world of government or established private sector organizations. On the other hand, with economic displacement resulting in unemployment, retrenchment and the introduction of "enterprise culture" education in tertiary institutions, Tiv graduates are now exploring opportunities to engage in entrepreneurship.

\section{Conclusion}

The findings and analyses of this paper are consistent with the opinions in entrepreneurship theories that the socio-cultural environment and circumstances of a people influence their behaviours and decisions in their social and economic lives, including decisions about entrepreneurship.The individual has a unique personality; however he or she is the product of society and subject to the values and influences of his/her society/ ethnic group. Therefore, the socio-cultural environment has significant impact on individuals which directly influences their decisions and actions. The qualitative analyses highlighted in this paper signal a mostly negative impact of the socio-cultural environment on Tiv individuals to entrepreneurial self employment. However, because of the new and emerging realities in Nigeria, socio-cultural values of ethnic groups, including that of the Tiv are changing. Therefore, Tiv individuals are urged to learn how to convert the weaknesses in their socio-cultural environment to advantage and to create opportunities to launch them into entrepreneurship. Business ownership is possible and can be enjoyable.

\section{References}

[1]. Abraham, R.C. (1934), The Tiv people. Lagos: Government Printer.

[2]. Akpor-Robaro, M. O. (2012), The impact of socio-cultural environment on entrepreneurial emergence: A theoretical analysis of Nigerian society. European Journal of Business and management: 4(16):172-182.

[3]. Aldrich, H. and Waldinger, R. (1990). Ethnicity and entrepreneurship. Annual Review of Sociology: 16:111-135.

[4]. Berger, B. (1991), The culture of modern entrepreneurship. In Berger, B. (1991). The Culture of Entrepreneurship. San Francisco California: ICS Press.

[5]. Bohannan, P. \& Bohannan, L. (1968), The Tiv economy. London: Longmans, Green \& Co. Ltd.

[6]. Burrows, R. (1991), The discourse of the enterprise culture and the restructuring of Britain: A polemical contribution. In Curran, J. and Blackburn, R (eds) Paths of Enterprise. London: Routledge. 
[7]. Chell, E., Haworth,J. \& Brearley, S. (1991), The entrepreneurial personality. London: Routledge.

[8]. Davidsson, P. (1995), Culture, structure and regional levels of entrepreneurship. Entrepreneurship and Regional Development, 7: 41-62.

[9]. Davidsson, P., \& Wiklund, J. (1997), Values, beliefs and regional variations in new firm formation rates. Journal of Economic Psychology, 18, 179-199.

[10]. Dia, Mamadou (1992), Indigenous management practices: Lessons for African management in the 1990s. In Ismail Serageldin and June Taboreff (eds) Culture and development in Africa: Proceedings of International conference held at the World Bank; Washington DC April 2-3 1992.

[11]. Drucker, P. F. (1985), Innovation and entrepreneurship. New York: Harper and Row.

[12]. East, R. (2003), Akiga's story: The Tiv tribe as seen by one of its members. Ibadan: Caltop Publications (Nigeria) Ltd.

[13]. Giannetti, M. \& Simonov, A. (2007), Social interactions and entrepreneurial activity. Downloaded from the social science research network: http//ssrn.com

[14]. Gibb, A. (1996), Entrepreneurship and small business management: Can we afford to neglect them in the 21st century business school? British Journal of Management: 7: 309-321.

[15]. Gibb, A. (1987). Enterprise culture, its meaning and implications for education and training. Journal of European Industrial Training: 11: 1-38

[16]. Gilder, G. (1971). The spirit of enterprise. New York: Simon and Schuster.

[17]. Haggett, P. (1983). Geography: A modern synthesis. New York: Harper Collins.

[18]. Harrison, L.E \& Huntingdon, S. P. (2000), Culture matters. New York: Basic Books.

[19]. Hayton, J., George, G. \& Zahra, S. (2002), National culture and entrepreneurship: A Review of behavioural research. Entrepreneurship Theory and Practice, 26(4):46.

[20]. Herbig, P. (1994), The innovation matrix: Culture and structure prerequisites to innovation. Westport, CT: Quorum.

[21]. Herbig, P. A., \& Miller, J. C. (1992), Culture and technology: Does the traffic move in both directions? Journal of Global Marketing, 6, 75-104.

[22]. Hofstede, G. (1980), Culture consequences: International differences in work-related values. Beverly Hills, CA: Sage Publications.

[23]. Hofstede, G. (1991), Cultures and Organisations: Software of the Mind; Intercultural Cooperation, its importance for survival. London: McGraw Hill.

[24]. Hornaday, J. \& Aboud, J., (1971), Characteristics of successful entrepreneurs. Personnel Psychology: 24:141-153.

[25]. Johannisson, B (1993). Designing supportive contexts for emerging enterprises. In Karlsson et al. (eds) Small Business Dynamics. London: Routledge.

[26]. Joynt, P. \& Warner, M. (1996). Managing Across Cultures. London: International Thomson Business Press.

[27]. Lamont, M. (1994). Money, morals and manners: The culture of the French and American upper middle class. Chicago: University of Chicago Press.

[28]. Licht, A.N. (2007), The entrepreneurial spirit and what the law can do about it. Comparative Labour Law and Policy Journal: 28: 817-62.

[29]. Light, I. \& Rosenstein, C. (1995), Race, ethnicity and entrepreneurship in urban America. New York: Aldine De Gruyter

[30]. Makar, T. (1994), The history of political change among the Tiv in the $19^{\text {th }}-20^{\text {th }}$ century. Enugu Fourth Dimension Publishing Company.

[31]. McClelland, D. C. (1961), The achieving society. New York: Irvington.

[32]. McGrath, R.G. Macmillan, I. \& Schebert (1992), Elitist, risk takers and rugged individuals? An exploratory analysis of cultural differences between Entrepreneurs and non Entrepreneurs. Journal of Business Venturing 7(2) 115-136.

[33]. McGrath, R.G., MacMillan, I.C., Yang, E.A., \& Tsai, W. (1992), Does culture endure, or is it malleable? Issues for entrepreneurial economic development. Journal of Business Venturing 7: 115-135.

[34]. Mitchell, R. K., Smith, B., Seawright, K. W., \& Morse, E. A. (2000), Cross-cultural cognitions and the venture creation decision. Academy of Management Journal, 43, 974-993.

[35]. Morrison, A. (ed) (1998). Entrepreneurship: An international perspective. Oxford: Butterworth-Heinemann

[36]. Mueller, S. L., \& Thomas, A. S. (2000). Culture and entrepreneurial potential: A nine country study of locus of control and innovativeness. Journal of Business Venturing, 16, 51-75.

[37]. Naffukho, F. M. (1998). Entrepreneurial skills development programmes for unemployed youths in Africa: A second look. Journal of Small Business Management: 36(1)

[38]. Ronstadt, R.C. (1984), Entrepreneurship. Dover, MA: Lord Publishing

[39]. Shapero, A. (1975), Entrepreneurship and economic development. Project ISEED, Ltd. (Milwaukee, WI: Centre for Venture Management): Summer

[40]. Shiller, R. J. (2005). The culture of entrepreneurship. Downloaded from www.project-syndicate

[41]. Tseayo, J. I. (1975). Conflict and incorporation in Nigeria: The integration of the Tiv People. Zaria: Gaskiya Corporation.

[42]. Thomas, A.S. \& Mueller, S.L. (2000), A case of comparative entrepreneurship: Assessing the relevance of culture. Journal of International Business Studies: 3(2): 287- 299.

[43]. Thompson, M. \& Wildavsky, A. (1986), A poverty of distinction: From economic homogeneity to classification of poor people. Policy Sciences: 19: 163-199.

[44]. Weber, M. (1976), The protestant ethic and the spirit of capitalism. London: Allen and Urwin. 